\title{
The effects of long-term eplerenone treatment in pediatric renal transplant patients
} \author{
Mehmet Haberal ${ }^{3}$

\footnotetext{
${ }^{1}$ Department of Pediatric Nephrology, Baskent University Hospital, Ankara, Turkey

${ }^{2}$ Department of Pathology, Baskent University Hospital, Ankara, Turkey

${ }^{3}$ Department of General Surgery, Baskent University Hospital, Ankara, Turkey
}

Esra Baskin ${ }^{1}$, Kaan Gulleroglu ${ }^{1}$, Handan Ozdemir ${ }^{2}$, Aysun C Yilmaz ${ }^{1}$, Ebru Ayvazoglu Soy ${ }^{3}$, Gokhan Moray ${ }^{3}$,

Background: Previous data strongly suggest that mineralocorticoid receptor (MCR) antagonists prevents acute kidney injury, proteinuria, and progressive renal disease. However, there is little information about this approach in renal transplant patients. Eplerenone is a potent and high selective MCR antagonist. In this study we aimed to investigate the effect of long-term eplerenone administration in children with chronic allograft dysfunction.

Methods: Twenty-five of 165 renal transplant children with biopsy-proven chronic allograft dysfunction and glomerular filtration rate $>40 \mathrm{~mL} / \mathrm{min} / 1.73 \mathrm{~m}^{2}$ were included to the study. Eight patients received additional $25 \mathrm{mg} /$ day eplerenone for 3 years (group 1), 17 patients did not receive eplerenone (group 2). Kidney biopsy samples were evaluated at baseline and after 36 months. The outcomes and laboratory findings of patients were compared.

Results: There were no differences in age, sex, type of immunosuppression, donor type, follow-up time, and serum $\mathrm{K}$ levels. Although basal serum creatinine values and spot urine protein-creatinine ratio were similar in both groups, they increased significantly in group 2 at 36 months $(P<0.05)$.

Conclusions: Our study showed that the long-term eplerenone administration decreased proteinuria and attenuates the progression of chronic allograft dysfunction in selected pediatric transplant patients. Further studies are needed for determining the potential benefit of MCR antagonists in pediatric patients.

Corresponding author: Esra Baskin

E-mail: rectorate@baskent.edu.tr

(c) The Korean Society for Transplantation

This is an Open Access article distributed under the terms of the Creative Commons Attribution Non-Commercial License (http://creativecommons.org/licenses/by-nc/4.0/) which permits unrestricted non-commercial use, distribution, and reproduction in any medium, provided the original work is properly cited. 